\title{
THE PROJECTS METHOD IN THE CULTURE OF REGION DISCIPLINE IN THE TOURIST EDUCATION
}

\author{
Margarita Gudova $^{1 \star}$, Natalia Kiseleva², Evgeniy Kiselev ${ }^{3}$ \\ ${ }^{1}$ Dr., Ural Federal University, Russia, marggoodova@gmail.com \\ ${ }^{2}$ Ms., Ural Federal University, Russia, kisi13.01@mail.ru \\ ${ }^{3}$ Mr., Ural State Economy University, Russia, kisi13.01@mail.ru \\ ${ }^{*}$ Corresponding author
}

\begin{abstract}
The article is devoted to the actual problem of development in the professional tourist education. The tourist education in contemporary Russia is reflecting the process of formation the tourism as a new cultural phenomenon and business industry. The Russian contemporary tourism service market demands the new approach for the tourist education, in which process of the specialist learning in tourism must comply with the requirements of service technology about tourists and excursionists. Now the tourist education of guides is newly subject to matter in the education science.

Our article is focused on the issue of learning in disciplines about the culture of the region in the process of professional training in the sphere of tourism. We discussed the educational effectiveness of problemoriented and project-based learning methods and the method of the project in the learning about the Culture of region tourist's disciplines. The essence of this method consists in the creation of the excursion project about several objects of interests in the cultural region. The plan of the project includes the stage of lections about objects of interesting with visits to the sights of the region: historical, ethnic and art museums, art galleries, religious centres and Christian Orthodox monasteries, libraries, zoos, natural parks, and reserves. Lectors from the university and members of those institutions work together and have a function of teaching and tutoring. After then there are some workshops on the objects of interesting, where students have researched a lot of interesting buildings, pictures, monuments, artefacts, shows, animals, trees and flowers, and the tourist reality is created from them. The last stage of the project contains the elaborating of new excursion: the writing the text of guidebook and the exhibition of photographs for the guidebook, and the recording the text of the audio guide.

In the summary, we concluded that the problem-oriented and project-based learning methods and the method of the project are the most effective one for the learning of new generations of guides for the tourist industry.
\end{abstract}

Keywords: problem-oriented and project-based learning, professional competence, learning outcomes, guide's training 


\section{INTRODUCTION}

A growing consensus about educational effectiveness of problem-oriented and project-based learning methods is the fact of educational science now (Mingxin, Ardeshir, 2016). Our article is devoted to the actual problem of development in the professional tourist education in this way in Russia. The tourist education in contemporary Russia is reflecting the process of formation the tourism as a new cultural phenomenon and business industry. The Russian international tourism industry was founded in 1991, "was born the new tourist, he was accustomed to dialogue and interactive support during educational and leisure activities" (Kiseleva, 2016, p. 365). Until that time, domestic tourism has mainly developed. In the new situation, the tourism industry has begun developed very quickly. In this industry were selected new specialties. It was necessary to educate specialists for the new labour market. Today the Russian tourism service market demands the new approach for the tourist education, in which process of the specialist learning in tourism must comply with the requirements of service technology about tourists and excursionists. Now the tourist education of guides is newly subject to matter in the education science. And questions of applying the problem-oriented and project-based learning in the education for tourist industry would be in the focus of this article. This aspect is new for the education science. Earlier discussions about problem-oriented and projectbased learning were concentrated scientists attention on an education of engineers, teachers, managers or medicine personal, not special for tourist guides (Mingxin, Ardeshir, 2016), (Aguiar-Díaz, Díaz-Díaz, Ballesteros-Rodríguez, De Sáa-Pérez, 2015), (Randall, Howell, Petrie, 2010).

\section{METHODOLOGY}

We would concentrate on the training of excursion guides in the High School. The profession of excursion guide involves erudition, oratorical and organizational skills and sociability. This training includes two group of competence. The First group of professional competence consists in the ability to communicate with tourists, to market the excursion product and to provide tour service. The Second group of professional competence assumes the skills on projects in the excursion service. "The development of professional competence is the key point of excursion guides professional education" (Dashkova, 2012).

The communicative competence is developing in several directions. The guide must be able to communicate with tourists on a variety of issues: about the weather, the traditional dressing, the suitable wearing, the historical persons and events, local cuisine and the sights. The guide should be able to be enthralling and inspiring for tourists. Today's travelers want the unique impressions and new experiences, which they will retrieve from memory for life (Roser, Maroto, Berciano, 2017) The second direction of development is the skill in communication with a tourist group. The guide ensures that the whole group of tourists participated in the tour activities from the start to the finish, and consumed travel services in the best possible conditions. Another direction of guide's communication is the business communication with partners: tour firms, transfer firms, hotels, restaurants, museums, concert halls, theatres, galleries and libraries and so on. A new direction in the communication group of competence is the tools of information technology to provide services of excursion guide.

The projects competence is very complexity, "it includes cognitive, representational, organizational elements" (Voytenko, 2016, p.87). The knowledge about sights should be interesting, comprehensive and scientific. The representation should be exciting: emotional, varied and memorable. All organizational issues should be considered. Very important skills of an excursion guide consist in creation the object of tourist interest from an object of everyday reality. It's very difficult case for the education process.

\section{RESULTS}

We discussed the problem-oriented and project-based learning in the Culture of region tourist's disciplines. The essence of project's method consists in the creation of the excursion project about several objects of interests in the cultural region. Project's method allows us to consider the actual them, which exist on the tour's market of excursions. Project's method helps to use various modes for the training process, engages the knowledge from many others disciplines. Student, who creates the project, develops his cognitive skills, makes his products, evaluates a variety of factors, promotes popular tour product on the market of excursion services. All of this takes place long before entering the professional market. Also, the project's method helps for students to learn the technology of creation excursion product. This advantage is based on the strong plan of project's activity and supervising by professional guides.

The plan of the project includes the stage of the definition of the trends of the season, the wording of the theme under the trend of the season, the choice of sights and justification of the style and details of the guide's story about the object, collecting data about the object, and presentation of results and defense of the project. 
The choice of project's theme is agreed with the student, his personal and professional interests. At the same time, the topic must conform to the current tourist trends and learning situations. This personalized approach ensures that creative execution of the project by the student.

The development of the route of the tour takes place in the context of urban spaces: religious centers and Christian Orthodox monasteries, natural parks or industrial museums, art galleries, libraries, zoos, and reserves.

There are traditional sights for tourists, who visited Yekaterinburg or region. It is such objects as Verkhoturye Kremlin, the monastery complex Ganina Yma, Dolmatov monastery and so on. There are some difficulties in the excursion narrative about each object. Every sacred site has own historical context and emotional background for narrative. Verkhoturye Kremlin is devoted to the colonization of Ural by Russian Empire and promotion Orthodox religious in the life of local Ural's peoples. Ganina Yma is the place, where last Russian Tzar was killed with all his family. It's very important to comply with the required style and to elaborate special focus for discussion such famous places of tourist's interest and to produce the positive brand of a region.

Besides that students learn to make an excursion in ordinary places of city - industrial parks, fitness centres, clubs, residential district, libraries. These urban spaces are shown as the places with typical city's values.

Another type of excursion objects - historical and ethnographical parks, natural parks. The narrative about such parks must contain a lot of information about local nature, and this on must be an unexpected and intriguing. In general, the narrative must be environmentally friendly. "The Land of Ancestors" is the most interesting object among natural parks of Ural. This is a unique place in the region, where the traditional life of the indigenous population can be to discover. There are so many archaeological and ethnographic artifacts on this object. Such non-attractive artifacts students must turn to the simulators for survival in natural conditions.

One of the most difficult for student's narrative object is industrial landscape. The industrial landscape of Ural includes so many metal and mechanic factories, arsenals. Most of these facilities have a long been closed regime enterprises. They have only recently become accessible to tourists and have opened its corporate museums. In these facilities, students learn to talk about the mental features of mining and factory civilization.

Thus, students try to plan an excursion narrative, using all the historical-cultural and natural-geographical resources of the Ural region. The excursion narrative is the synthesis of knowledge obtained in the study of local history subjects.

The next stage of work on the project consists in co-option with the institution of excursion. Lectors from the university and members of those institutions work together and have a function of teaching and tutoring. This stage of the project contains the elaborating of new excursion: the writing text of guidebook and the exhibition of photographs for the guidebook, and the recording the text of the audio guide. The student makes a photo gallery of the facility and places them on a professional website. The working with a professional website is an important part of professional competence. "The creation of multimedia texts in the contemporary culture has particular importance" (Gudova, 2015, p.29). It's allowed to promote new excursion product by students for the real market of tours. The text of the guidebook, illustrated with photographs and documents, created in the collaborative process, took edited and published for using by excursion institutions. The results of student's project are the photos of the tour, the excursion narrative, and audio guide.

The defense of the project takes place directly on the tour route when the student works with the group of tourists. Students from the same educational groups are most often members of this tour group. This triggers the mechanism for mutual check and assessment of projects with students and colleagues guides. Recommendations and gratitude of tourists are the highest ratings of student's project.

This technique has been tested in over 7 years. Learning outcomes included the generated communication skill at all level of professional interaction skill development of the tour route. A primary result of the use of the project method is that the student simultaneously with the process of learning gets the hang of working on a real tour of the facilities of a modern tourist industry together with professionals in this field.

\section{SUMMARY}

In the summary, we concluded that the problem-oriented and project-based learning in the Culture of region tourist's disciplines and the method of the project are effective as well in the learning new generations of guides for the tourist industry as in the other high-education fields. 


\section{REFERENCE LIST}

Aguiar-Díaz, I., Díaz-Díaz, N.L., Ballesteros-Rodríguez, J.L., De Sáa-Pérez. P. (2015) University - industry relations and research group production: is there a bi-directional relationship? Industrial and Corporate Change.

Vojtenko, M.V. (2016). Vozmozhnosti formirovanija professional"nyh proektnyh kompetencij v vysshem turistskom obrazovanii. Sovremennye naukoemkie tehnologii. 2016.Vol. 5-1.

Gudova, M. (2015). Chtenie v jepohu postgramotnosti: kul'turologicheskij analiz. Avtoref. ... dis. d-ra kul'turologi.

Dashkova, E. (2012). Professija «jekskursovod»: opyt kompetentnostnogo analiza.

Http://sociosphera.com/publication/journal/2012/171/professiya_ekskursovod_opyt_kompetentnostnog o_analiza/

Kiseleva, N. (2016). Kollekcija puteshestvij (vystavka «Vostochnyh kollekcij» v Sverdlovskom oblastnom kraevedcheskom muzee). Ustojchivoe razvitie Rossii: vyzovy, riski, strategii : materialy XIX Mezhdunarodnoj nauchno-prakticheskoj konferencii Gumanitarnogo universiteta, 12-13 aprelja 2016 goda. Vol.1.

Mingxin, L., Ardeshir F. (2016) Applying Problem-Oriented and Project-Based Learning in a Transportation Engineering Course. Journal of professional issues in engineering education and practice. 2016. 142. Vol.3

Randall D.S., Howell, S.L., Petrie, J.A. (2010). A Review of Trends in Distance Education Scholarship at Research Universities in North America, 1998-2007. International review of research in open and distance learning. 2010. 11. Vol.3

Roser C.M., Maroto, S.F.J.L., Berciano, G.S. (2017) Evaluating educational programs in museums: a new perspective. Bordon-revista de pedagogia. 2017. 69. Vol.1. 